\title{
NEWS AND REVIEWS
}

Commonwealth Journal of Local Governance

Issue 2: January 2009

http://epress.lib.uts.edu.au/ojs/index.php/cjlg

\section{Peter McKinlay}

Auckland University of Technology, New Zealand

Governing Cities in a Global Era: Urban Innovation, Competition and Democratic Reform Robin Hambleton and Jill Simone Gross (Palgrave MacMillan, New York, 2007.)

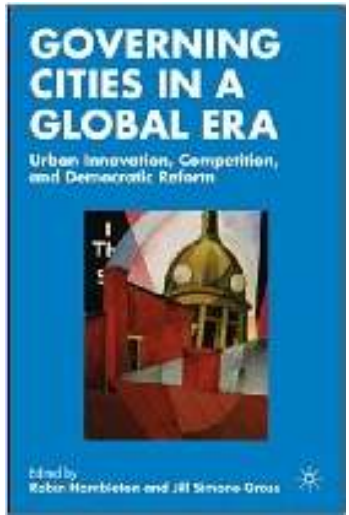

Robin Hambleton and Jill Simone Gross have assembled a collection of papers which powerfully supports their argument that "those concerned with the future of cities, whether as academics or practitioners, should devote more time to instrumental learning from abroad." Contributions range widely from the influence of globalisation and urbanisation, to the importance of understanding the unique impact of our own context; from innovation in the leading 'world cities' of the developed world, to the seemingly intractable problems of cities in the developing world; from celebrating the importance of a shift from government to governance, to contributions highlighting the potential of governance to undermine local democracy; and from the role of leadership to the dangers of persistent managerialism.

A central theme throughout the book is the relationship between government, the formal institutions of the state, and governance - government plus the looser processes of influencing and negotiating with a range of public and private sector agencies to achieve desired outcomes. The editors in their opening chapter set out a focus on governing cities based on the argument that governance in the absence of strong government can lead to urban breakdown. Two contributions provide valuable empirical evidence on the shortcomings of an over-emphasis on governance.

Judd and Smith discuss the role of special-purpose authorities in urban development in the United States. These are stand-alone entities (often formed as special districts with their own independent revenue sources), typically established to develop and run major projects (stadia, convention centres, major cultural initiatives), usually to distance them from the uncertainties of public processes (consultation, referenda etc). The model is very much governance in terms of local 
government working with a range of public and private sector parties to establish and fund these entities. Judd and Smith argue that the public has been the loser by being distanced from local democratic accountability, citing research that: "historically, advocates for these major projects have invariably over-estimated use and revenues and under-estimated costs. The reasons are not hard to find. Working in a closed world of supporters of their projects, participants and the consultants who advise them share an interest in moving forward."

Davies considers partnership building in the UK within the framework of local governance. Drawing on his own and others' research he argues that "community participation is being subverted to managerial and technocratic ends." Evaluation of New Deal for Communities funding concluded: "the original assumption that partnerships should be given a strong degree of local flexibility and freedom has been steadily eroded." Essentially, the key condition for genuine partnership working, that partners respect each other's views and seek to achieve consensus, was not present. Government and managerial objectives overrode community interests.

From this reviewer's perspective the major interest of this work lies in its contributions to understanding different arrangements for metropolitan governance, including how they have evolved, and the effect of local context (historical, social, political, economic, geographic). Röber and Schröter, comparing institutional reform in Berlin, London and Paris, draw valuable attention to the importance of historical context, whilst at the same time highlighting a common theme of the search for a means of managing strategic decision-making at the level of the metropolitan region. It is not just London which has seen the importance of separating responsibility for regional strategic issues from service delivery.

Tsukamoto and Vogel review a range of literature on the role of the state in the rise of world cities, much of which argues that globalisation leads to decentralisation because of the need for localities to be internationally competitive: "nation states should promote devolution if they seek to enhance the competitiveness of their cities." Their own research, focused on twenty world cities, leads to the conclusion that "globalisation is almost as likely to lead to greater political centralisation as (to) decentralisation", with a major factor being intervention by central governments to promote development.

For this reviewer, the discussion of the role of the state would have benefited from considering the research on the hostility which many central governments have shown to the emergence of a strong metropolitan level (OECD 2004, Davoudi 2006). This has been an important factor in developments (or the lack of them) in metropolitan governance in, for example, Canada and Australia, where metropolitan regions such as Toronto and Sydney labour under dysfunctional governance arrangements. 
Kübler and Randolph's account of metropolitan governance in Australia through the Sydney experience is a timely reminder of the very high costs of failure to deal adequately with the challenge of metropolitan governance, as well as an illustration of the potential for local governments in a fragmented system to develop coping mechanisms. In this respect, Kübler and Randolph describe the emergence of strong collaboration amongst eleven councils in Western Sydney, driven by the failure of the state government to deal with a major infrastructure deficit. There is an interesting if somewhat loose parallel with Zhang's account of evolving urban governance in Shanghai, where building owner associations (commercial) and property owner associations (residential) have come to play an important role in urban governance, effectively filling a gap, driven by the incentive to protect their significant investments. At least where the inherent capability is present, it does seem that local governance will out.

Other contributors provide valuable insights into the role of leadership within local government, including John Nalbandian who considers the response of professionals to the conflicting forces of administrative modernisation and civic engagement, balancing new public management driven demands with the imperatives of local democracy. Nalbandian makes the very valuable point that the growing professionalism of local government management in recent years has further widened the capability gap between management and elected members, a phenomenon which is an increasingly significant issue in a number of jurisdictions.

In their concluding chapter, Hambleton and Gross end by revisiting two scenarios developed in their opening chapter for the future of cities - a balkanised world of fortified enclaves and widening social divisions, or a revitalisation of local democracy with cities re-establishing themselves as centres of culture and civilised living. Part way through this chapter they set out what this reviewer regards as the essential prerequisite for the optimistic scenario:

... it seems clear that higher-level governments have a responsibility to ensure that effective governance arrangements and resources are in place. In too many countries national governments are failing to rise to this challenge.... local leadership and an enlivened local democracy are crucial for urban success, but these local energies need to be orchestrated and supported by higher levels of government (state and federal in federal systems, national in unitary systems). This means ensuring that the powers, funding, and the configuration of local democratic institutions are suited to modern challenges rather than to a bygone era.

Hambleton and Gross have provided a very valuable resource for anyone concerned with the future of metropolitan and city governance. That said there are two things that they might like to consider. The first is the possibility of producing a layman's version capable of being easily assimilated by the typical elected member. The second is whether the global credit crunch, and the potential retreat from reliance on markets which have set so much of the context for urban development in recent years, might not justify a second edition revisiting some of the judgements about the forces driving the development of our cities. 


\section{References}

Davoudi, S. 2006. 'Polycentric Development and Metropolitan Governance', keynote speech to the International Conference on "Social Policy and Regional Development", Zagreb, Croatia.

OECD [Organisation for Economic Cooperation and Development], 2004. 'OECD Metropolitan Regions: What Role for the Central Governments?' Produced for the XVIIth session of the entretiens Jacques Cartier "Metropolitan governance: seeking consistency in complexity", Montréal, Quebec, 7-8 October 2004. 